\title{
GUIDELINES FOR THE MANAGEMENT OF UNETHICAL BEHAVIOUR IN HOMES FOR OLDER PERSONS
}

\section{Kim O’Donoghue}

Master's student

Department of Nursing Science, Rand Afrikaans University

\section{Karien Jooste}

DLitt et Phil

Associate Professor, Department of Nursing Science, Rand Afrikaans University

Corresponding author:kjo@edcur.rau.ac.za.

\author{
Annatjie Botes (deceased) \\ DCur \\ Professor, Department of Nursing Science, Rand Afrikaans University
}

Keywords: nursing auxiliaries; care workers; ethics; homes for older persons

\section{SUMMARY}

The purpose of this research study is to formulate guidelines to counteract unethical behaviour of auxiliary nurses and care workers in homes for the older persons.

The study explored and described:

- the perceptions and behaviour of auxiliary nurses and care workers relating to unethical behaviour in homes for older persons; and

- $\quad$ the perceptions of registered nurses relating to unethical behaviour of auxiliary nurses and care workers in homes for older persons.

To achieve the goal and the objectives of the research a qualitative approach was used in the research design and method. The objectives of the research began with a written narrative of an actual case of unethical behaviour in a home for older persons, on which auxiliary nurses and care workers in homes for the older persons in the Gauteng area were asked to comment. Two open-ended questions were asked. The results of this data were presented for comments to a focus group of registered nurses. This data was recorded for truth value. The population and sampling for phase 1 of the study consisted of 60 auxiliary nurses and care workers who worked in homes for frail older persons in Gauteng. The population and sampling for phase 2 of the study consisted of ten professional nurses working in homes for frail older persons in Gauteng. Purposive sampling was used to achieve saturation of data. The model of Lincoln and Guba (1985) was used to ensure trustworthiness. Ethical considerations were maintained throughout the study and consent was obtained from the respondents. The recommendations of the research were that attention should be given to the following: management in homes for the older persons, personnel selection and recruitment, orientation and in-service training programmes, and the ethical-legal aspects of caring for older persons should be addressed.

\section{OPSOMMING}

Die doel van hierdie navorsing is om riglyne te beskryf wat die onetiese gedrag van hulpverpleegkundiges en sorgwerkers in ouetehuise kan bekamp.

Die studie het die persepsies

- $\quad$ en gedrag van hulpverpleegkundiges en sorgwerkers rakende onetiese gedrag in ouetehuise ondersoek en beskryf;

- $\quad$ van geregistreerde verpleegkundiges rakende die onetiese gedrag van hulpverpleegkundiges en sorgwerkers 
in ouetehuise ondersoek en beskryf.

Om die oogmerke en doelwitte van die navorsing te bereik is ' $n$ kwalitatiewe benadering gevolg in die navorsingsontwerp en -metode wat gebruik is.

Die doelwitte van die navorsing het met 'n geskrewe verhaal van 'n werklike geval van onetiese gedrag in 'n ouetehuis begin. Hulpverpleegkundiges en sorgwerkers in twee ouetehuise in Gauteng is gevra om kommentaar daarop te lewer. Twee oopeinde-vrae is gestel. Die resultate van die data is aan ' $n$ fokusgroep van geregistreerde verpleegkundiges vir kommentaar voorgelê. Hierdie data is vir geloofwaardigheid getoets.

Die deelnemers vir fase 1 van die studie het bestaan uit 60 hulpverpleegkundiges en sorgwerkers wat in ouetehuise vir verswakte bejaardes in Gauteng gewerk het. Die deelnemers vir fase 2 van die studie het bestaan uit tien geregistreerde verpleegkundiges wat in ouetehuise vir verswakte bejaardes in Gauteng gewerk het. Doelbewuste steekproefneming is gebruik om soveel as moontlik data in te samel. Lincoln en Guba (1985) se model is gebruik om betroubaarheid te verseker.

Etiese oorwegings is dwarsdeur die studie gehandhaaf en toestemming is van die respondente verkry. Aanbevelings voortspruitend uit die navorsing was dat die volgende aandag behoort te geniet: die bestuur van ouetehuise, personeelkeuring en -werwing, oriëntering- en indiensopleidingsprogramme, en dat eties-wetlike aspekte van die versorging van bejaardes aangespreek moet word.

\section{INTRODUCTION AND RATIONALE}

The move towards optimal care for older persons has been motivated by certain factors, for instance, encouraging nurses to assume a greater role in ensuring the best care possible for the older persons. This focus shift is important, as people are living longer, and nurses must ensure that they also increase the quality of that prolonged life. The birth of democracy in South Africa saw the creation of the African National Congress' Reconstruction and Development Programme (1994), which spawned a national health programme that is based on equal health care rights for all. This includes older persons (ANC, 1994:42) and recognise that older persons are entitled to aspire to and attain the highest possible level of health.

In 1992, the Human Sciences Research Council (HRSC), at its University of Cape Town centre, conducted a think-tank on gerontology (Conradie \& Charlton, 1992:8). The then Regional Manager of the South African Nursing Association addressed the participants of the think-tank on problems experienced by the nursing profession in rendering care in homes for older persons. In introducing the topic, she referred to media reports on alleged malpractice and mistreatment in homes for the older persons. Complaints from concerned members of the public as well as family and friends of residents had also been received by various organisations involved in the care of older persons. The think-tank distinguished between mistreatment, elder abuse, and passive and active neglect. Examples of mistreatment identified were verbal abuse, physical abuse, financial exploitation, overmedication, theft, psychological abuse and institutionalisation abuse (which were seen as either individual or collective abuse). Passive neglect was identified as occurring when the care worker ignored the resident. This was not seen as a possible wilful act of neglect, but ineptness or inability on the part of the carer, seemingly from the lack of in-service education. Active neglect was identified when a care worker intentionally deprived or isolated the resident. This could be refusal to help the resident with basic daily needs such as bathing, dressing and eating (Conradie \& Charlton, 1992:6).

Both neglect and malpractice constitute unethical behaviour and, with the identification of these problems during the think-tank, this meant that standards of care in the homes for the older persons had dropped and that the residents were suffering as a consequence (Conradie \& Charlton, 1992:6). Quality care implies ethical care, and if standards of care have dropped, unethical behaviour is the result.

The question of standards in homes for older persons is becoming increasingly important to a growing number of people. This is because our societies have changed - older persons can no longer live at home and form part of the now non-existent extended family. All the members of the family work and there is no one to take 
care of the older persons in a home environment. This being the case, once older persons can no longer manage on their own, the logical step is for them to move to a home for the older persons. Taking care of older persons is challenging and complex. Consequently, today's auxiliary nurses and care workers need to have clinical nursing skills and knowledge of the ageing process (Breitung, 1987:v). If neglect and malpractice are prevalent in these homes, these problems need to be addressed. In order to establish why carerelated problems exist, it is important to define certain aspects.

Nursing care of older persons is seen as goal-oriented to provide quality care within a caring environment, as opposed to a curing environment. This simply means that the individual is nursed in a caring and pain-free environment. Within a caring environment, the auxiliary nurse and care worker must be educated to provide physical, ethical, moral and spiritual care. To be able to give this physical, ethical, moral and spiritual care, the nursing auxiliary and care worker must care and have respect for the older person's person. It would be impossible to give quality care if this was against the value system of the individual. To conduct oneself ethically, an individual must subscribe to the ethics and norms of society (Stephenson, 1988:43).

Wright (1998:3) states that negative staff attitudes towards older persons have long been cited as a major factor contributing to poor care for nursing home patients. These negative attitudes contribute towards a non-caring attitude among staff. This in turn results in negligence and neglect in homes for older persons and, as an older person has a right to quality nursing care, the auxiliary nurse and the care worker must be educated to perform these duties with knowledge and skill.

Clear written guidelines on the practice for the care of the older persons are sometimes absent but extremely necessary in directing nursing staff to provide quality nursing care. In this study, the purpose of the written guidelines is to direct the auxiliary nurse and care worker in their care of older persons, and to provide standards of care for the older persons.

Each old age home relies on the knowledge and skill of nursing practitioners to perform their nursing duties within a trusting relationship between management and staff. For the comfort and care of the resident, this involves feelings of safety and security during the interaction of management, staff and residents, thereby combating the problem of unethical behaviour of auxiliary nurses and care workers in homes for older persons.

\section{LITERATURE STUDY}

Research generally builds on existing knowledge. According to Polit and Hungler (1993:106), links between new research and existing knowledge are developed through a thorough review of prior research on the topic and through efforts to identify and appropriate a theoretical framework for the research problem.

The residents of homes for older persons experience life within the home and this life revolves around the nursing home staff. The nurse looms large in the life of the nursing home resident. The frail residents treasure the staff's attitudes towards them the most (Tellis-Nayak \& Tellis-Nayak, 1989:309). Unkind life experiences at home and in the home for older persons shape attitudes of indifference, apathy and cynicism among staff members, which may lead to unethical behaviour. The vulnerable resident then reaps the bitter harvest.

Economic conditions are an aspect of life experiences of the staff in old age homes that can also dictate values and attitudes as auxiliary nurses and care workers are usually very poorly paid. Another aspect is that staff come from diverse social and cultural backgrounds, which may influence the way in which an individual views the cultural and social patterns of the older persons' home. Wright (1998:14) states that when attempting to conceptualise the relationship between older persons' home staff's attitudes and quality care, the sociocultural environment of older persons homes needs to be viewed as determining attitudes towards behaviour, which fully determine actual care-giving behaviour.

During an archive review at the SANC, the researcher reviewed previous disciplinary hearings and several conclusions were reached. During the period from April 1979 to March 1991, the South African Nursing Council heard one hundred and seventy-one cases of disciplinary action against auxiliary nurses for being absent from their posts. Sixty-seven of these cases 
were nursing auxiliaries from homes for the older persons. Twenty-nine nursing auxiliaries were convicted of theft from patients in hospitals and nursing homes. There were twenty-one cases of assault on patients by nursing auxiliaries in both provincial and nursing homes. Sixteen cases of forgery and fraud committed by nursing auxiliaries were reported. In 1998, eighteen cases of malpractice against nursing auxiliaries were heard and The South African Nursing Council suspended seven of them for this. It seems that unethical behaviour of auxiliary nurses and care workers is a problem in the health services, particularly in homes for older persons.

\section{PROBLEM STATEMENT}

To state the research problem, the following narrative is relevant to outline the context of the research study:

While a sister did her rounds after breakfast in an old age home in Johannesburg, a resident called her and said, "Look what 'they' have done to me while bathing and dressing me". She showed the sister finger marks and bruises on her arms and legs. "But please don't mention my name as I shall be victimised". This is but one example of unethical behaviour caused by manhandling of the residents. Quite often the sister in charge discovers these situations on doing her rounds as nobody has reported any such incidents.

In practice, there are no written guidelines that can be followed to deal with this situation as described in the above narrative, and the need to provide these guidelines to protect the older persons is thus evident.

The following research questions were asked that were relevant to the problem statement:

- What are the factors and reasons contributing towards unethical behaviour in homes for the older persons by auxiliary nurses and care workers?

- How can unethical conduct by auxiliary nurses and care workers in homes for older persons be resolved?

- Which guidelines should be described to direct the behaviour of staff members in caring for older persons?

\section{PURPOSE AND OBJECTIVES OF THE}

\section{RESEARCH}

The purpose of the research was to formulate guidelines to facilitate solutions to the problems regarding the unethical conduct of auxiliary nurses and care workers in homes for older persons.

To research the purpose, the following objectives were formulated:

- to explore and describe the perceptions of the auxiliary nurses and care workers in relation to factors contributing to unethical behaviour in homes for older persons;

- to explore and describe the perceptions of the registered nurses in relation to factors contributing to the unethical behaviour of auxiliary nurses and care workers in homes for older persons; and

- to formulate guidelines for the practice situation in homes for older persons.

\section{CONCEPTS}

Ethics is defined as standards of conduct and good behaviour based on moral judgements (Grogar-Murray \& DiCroce 1997:100). It is the science of morals in human conduct; a set of rules guided by moral principles. The Oxford Dictionary describes the word ethical as relating to moral, especially concerning human conduct - in other words, morally and behaviourally correct conduct. Conversely then, unethical refers to unscrupulous behaviour within a specific context (Concise Oxford Dictionary, 1951).

Nursing auxiliaries enrol with the South African Nursing Council (SANC, No. R1571, 1989) under Nursing Act No. 56 of 1978 and, as their scope of practice is limited, a registered nurse must supervise them. The auxiliary nurse is assisted in her duties by the care worker to provide basic nursing care. The care worker is not enrolled with the Nursing Council. Many homes for the older persons employ care workers as the cost involved is not as high as when employing auxiliary nurses. This in itself constitutes a problem, as the care worker course is very limited and there is usually very little training available.

In her thesis on cultural sensitivity in homes for the older persons, Perold (2000:6) states that $40 \%$ of 
nursing personnel in homes for older persons are care workers who provide care to older persons under the supervision of a registered nurse.

A registered nurse is a person who has completed the minimum requirements for the education and training of a nurse (general, psychiatric and community) and midwife leading to registration with the South African Nursing Council (South African Nursing Council, 1985).

Guidelines refer to those processes that lead to giving advice, counselling, directing, helping, instructing and teaching those who need to be guided in specific situations (Concise Oxford Dictionary, 1951).

\section{RESEARCH DESIGN AND METHOD}

A qualitative, explanatory, descriptive and contextual design and research method, in accordance with Mouton and Marais (1990:43-44, 51), were used.

\section{Population and Sampling}

The population was all registered nurses $(N=20)$; auxiliary nurses $(\mathrm{N}=15)$ and care workers $(\mathrm{N}=165)$ practising in old age homes with a frail care section in the Gauteng area.

The target population identified for objective 1 of the study was the entire population, in which auxiliary nurses and care workers provided basic nursing care in homes with a frail care section in the Gauteng area, under the supervision of a registered nurse $(N=180)$. A purposive sample (Burns \& Grove, 1993:246), consisting of five auxiliary nurses and 55 care workers, was drawn from these homes for older persons $(N=60)$. A purposive sample (Burns \& Grove, 1993:246), consisting of ten registered nurses, was chosen from these homes for the older persons. A pilot study was undertaken and the participants did not participate in the main study.

\section{Data Collection}

The data collection in objective 1 was conducted through a narrative of a previous incident of unethical behaviour (Brink, 1996:11), which was given to the target group of auxiliary nurses and care workers. They were required to answer questions on an actual incident of unethical behaviour in a home for the older persons. The story told is as follows:

"Mr A is an 80-year-old confused man in the frail care of an older persons' home. It is 8 in the morning and the care worker has been instructed by the sister to bath $\mathrm{Mr}$ A. He resists and picks up his walking stick. The care worker thinks he is going to hit her and grabs the stick out of his hand and hits him over the head causing a cut that bleeds."

- What do you think about the behaviour of the auxiliary nurse/care worker?

- Describe the possible reasons for this behaviour.

The method of data collection for objective 2 was to conduct three focus group interviews with the registered nurses to obtain their perceptions of unethical behaviour in homes for the older persons by auxiliary nurses and care workers. A Carte Blanche videotape, screened on M-Net television in 2000, was the point of departure of the focus group interviews. The videotape exposed the unethical behaviour of auxiliary nurses and care workers and their perceptions of this behaviour in homes for older persons (also addressing the outcome of objective 1). The questions asked of the participants in the focus groups were the following (objectives 2 and 3):

- What are the factors and the reasons for the unethical behaviour of auxiliary nurses and care workers in homes for the older persons?

- How can the problem of the unethical behaviour of auxiliary nurses and care workers in homes for the older persons be resolved?

These questions directed the research in formulating guidelines for the practice in homes for the older persons (objective 4).

\section{Data Analysis}

In the initial process of analysis, the researcher can choose from two strategies, namely horizontal and vertical 'passes' of the data. Vertical passes involve:

- concentrating on one section of the data and analysing it before moving on;

- reflecting on and reviewing the data in the section; and

- looking for insights and feeding them back into the data collection process. 
The horizontal approach is more holistic than the vertical pass. However, researchers not only analyse according to the methods they adopt, but they also have different personal styles, which demand different ways of looking at the data.

The following horizontal strategy was followed in the process of analysis (Holloway \& Wheeler, 1996:238):

- reading the data and looking at themes, taking in the overall picture (Tables 1 and 2);

- reflective and in-depth reading of the data to find supporting evidence of underlying processes to address unethical behaviour in homes for the older persons; and

- re-reading for elements and processes in formulating guidelines from the identified underlying processes.

The four main underlying processes identified during the empirical data, which led to the formulation of guidelines, were:

- the use of an effective management style in homes for the older persons;

- effective recruitment and appointment of suitable candidates to care for the older persons;

- the need for orientation programmes and ongoing in-service training programmes; and

- acknowledgement of the existing legal and ethical framework that should be used as a guideline for the behaviour of personnel in homes for the older persons.

\section{Trustworthiness}

The model of Lincoln and Guba (1985) was used to ensure trustworthiness of the research. Credibility was ensured through prolonged engagement and persistent observation of the researcher over a period of 30 years while working in homes for the older persons and through regular contact with the two focus groups, as well as in-depth discussions with colleagues on the problem of the unethical behaviour of auxiliary nurses and care workers in homes for the older persons. Triangulation of sources was described by using three data sources: the registered nurses, the auxiliary nurses and care workers as well as confirmation through a literature study. Lines of evidence through note taking, the recording of data, discussions with colleagues about the problem, as well as the supervision of a mentor in charge of the progress of the research also ensured credibility. Peer group debriefing and the use of an expert co-coder with a doctorate in nursing science ensured trustworthiness. To maintain transparency, a dense description was undertaken that ensured a complete description of the research design and the literature control.

\section{Ethical Considerations}

The registered nurses, auxiliary nurses and care workers were given a covering letter, explaining the reasons and importance of the research. Confidentiality was assured and the respondents could choose whether to participate or to withdraw. The respondents were also assured of anonymity. Informed consent was obtained from the respondents and they were assured that they could withdraw at any stage of the research.

Ethical clearance was obtained from the ethical committee of the residential university where the researcher was registered for the postgraduate study.

\section{INTERPRETATION OF DATA}

Table 1 only indicates examples of raw data that were interpreted and lead to certain findings. The raw data given by nursing auxiliaries and care workers that lead to the interpretation of certain factors that are related to education and training that contribute towards unethical behaviour are outlined in Table 1. The same process was followed for interpretation of all the raw data towards identifying factors that contribute towards unethical behaviour.

\section{FINDINGS}

Auxiliary nurses and care workers described the following factors as contributing to unethical conduct (transcribed raw data from the narratives given by participants in Table 2):

In Table 3 the registered nurses described the following contributing factors related to unethical conduct in homes for the older persons (see Table 3): 
Table 1: Examples of raw data that were interpreted as contributing to unethical behaviour

\begin{tabular}{|l|l|}
\hline \multicolumn{2}{|l|}{ Factors related to education and training } \\
\hline $\begin{array}{l}\text { "The behaviour of the care worker was very } \\
\text { bad and was a lack of knowledge of her job" }\end{array}$ & Lack of knowledge and training \\
\hline $\begin{array}{l}\text { "She is not trained with skills of how to } \\
\text { assess and judge the condition of the patient" }\end{array}$ & $\begin{array}{l}\text { Inability to assess or judge the condition of } \\
\text { the patient }\end{array}$ \\
\hline $\begin{array}{l}\text { "Lack of tender care which makes her the } \\
\text { competent nurse" }\end{array}$ & Lack of communication skills \\
\hline $\begin{array}{l}\text { "What the care worker did in that case is } \\
\text { absolutely wrong and unprofessional" }\end{array}$ & Lack of professional behaviour \\
\hline
\end{tabular}

Table 2: Factors identified by nursing auxiliaries and care workers

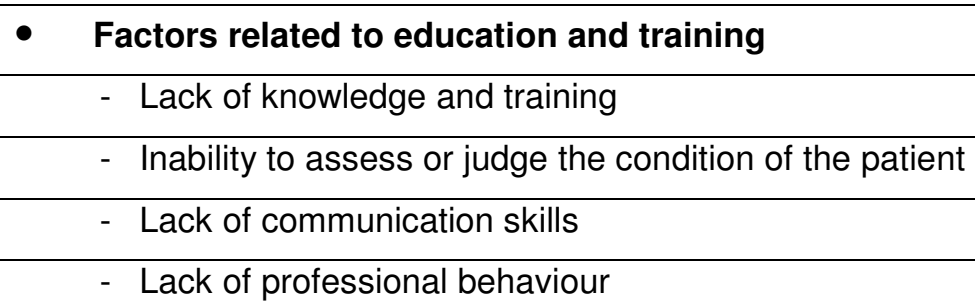

- Factors related to orientation and in-service education

- Not informed about the condition of the patient

- Do not understand the demands of the older persons

- Medico-legal hazards 
Table 3: Factors identified from registered nurses during the focus groups

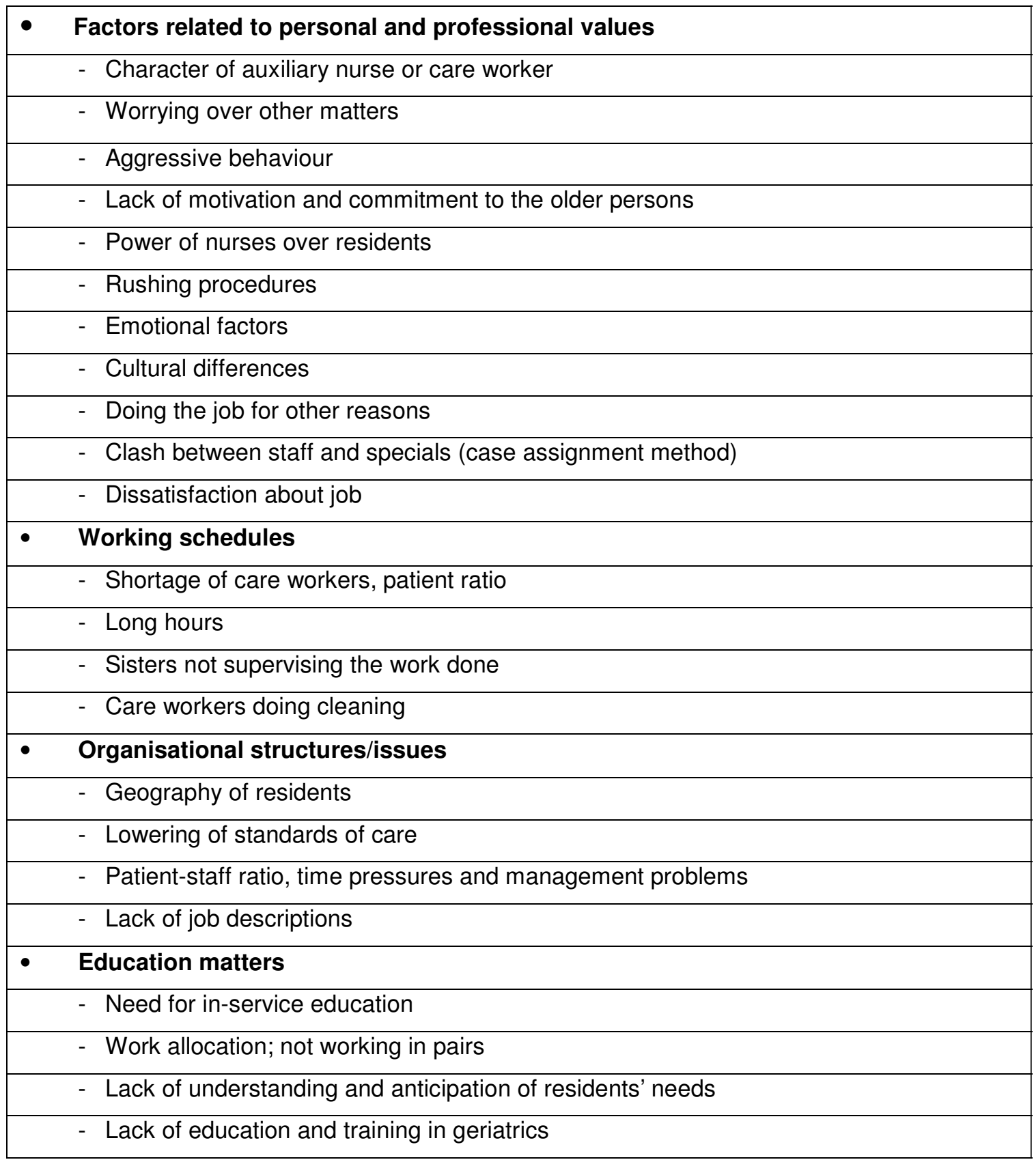

\section{CONCLUSIONS, DISCUSSION AND GUIDELINES}

From the empirical data and the literature study the following guidelines were formulated for nurse managers in homes for elderly people:

\section{Guideline 1}

The manager in charge of a home for older persons should use a combination of directive and participative management styles

\section{Rationale}

From the factors identified in the findings as the underlying causes of unethical behaviour in homes for the older persons, it was evident that the auxiliary nurses and care workers worked long hours and did not understand what was expected of them in the work situation. A situation of no supervision, a shortage of care workers and an unsatisfactory patient to staff ratio are experienced. A directive and participative style of management seems the most suitable form of management to counteract unethical behaviour in homes for the older persons (Muller, 1998:136). 


\section{Action}

A directive management style must be practised to prevent unethical behaviour in homes for the older persons. This includes the formulation of policy for the old age home and describes procedure manuals used for orientation and in-service education purposes so that the auxiliary nurses and care workers know exactly what is expected of them. Attention must be given to the patient to staff ratio. Through a directive management style, the auxiliary nurse and care worker must be made aware of the routines, procedures, job description, job requirements, task description, duty roster, the process of delegation of the workload, as well as the evaluation process used to identify problem areas and the solution to these problem areas (Muller, 1998:156).

An organogram that reflects the line of the hierarchy in the old age home must be accessible to the auxiliary nurse and the care worker so that there is no confusion about whom to contact when a problem arises.

A participative management style is used to prevent unethical behaviour by involving the auxiliary nurse and care worker in the formulation of procedures and asking for their opinions in creating a feeling of belonging and being part of the nursing care team (Muller, 1998:136). In situations of unethical conduct, regular meetings need to be held with the auxiliary nurse and care worker to involve them in finding solutions to these situations. It was ascertained in the findings that the auxiliary nurse and care worker lacked a caring attitude and this contributed towards unethical behaviour in homes for the older persons.

\section{Guideline 2}

When recruiting prospective auxiliary nurses and care workers, a suitable candidate should be appointed only after being properly interviewed and her personal and professional values and attitudes in respect of the older persons resident have been assessed. The latter can be determined by, for example, letting the candidate state her own personal nursing philosophy and discussing the relevance of the code of ethical conduct relevant to the nursing profession.

\section{Rationale}

From the factors identified in the findings as the under- lying causes of unethical behaviour in homes for older persons, it was evident that auxiliary nurses and care workers presented personal problems, values and attitudes that were inconsistent with the values and attitudes necessary to care for the older persons (Aroskar, 1983:20). It is therefore important to assess the positive professional values and attitudes when interviewing the prospective auxiliary nurse and care worker, before accepting them as employees to care for older persons (Bandman \& Bandman, 1990:10).

The factors that were identified from the raw data, as related to professional values were: caring about older persons, honesty, control, reliability, empathy, patience, respect, dedication, discipline, keeping personal problems out of the work situation, absence of aggressive behaviour, motivation, cultural sensitivity, hospitality, satisfaction, and doing the job for reasons of caring for older persons (Stephenson, 1988:43).

\section{Action}

To prevent unethical behaviour in homes for older persons, the selection process should include a set of criteria, such as previous work experience with older persons and a personal reference from a former employer and/or minister regarding the person's character, so that the suitability of the auxiliary nurse and care worker can be assessed properly and their opinions towards older persons can be established. Thus, selection, utilisation, motivation and recruitment are important in preventing unethical behaviour in homes for the older persons (Muller, 1998:220).

\section{Guideline 3}

Orientation programmes and ongoing in-service training programmes must be in place and should be updated regularly.

\section{Rationale}

From the factors identified as the underlying causes of unethical behaviour in homes for older persons, it was evident that orientation programmes and in-service training programmes for auxiliary nurses and care workers are necessary to prevent unethical behaviour. The factors identified were: lack of education and training in homes for older persons, a lowering of standards, lack of communication skills and lack of knowledge regarding professional behaviour. Reilly and Oesnan 
(1985:220) refer to ethics as "standards of conduct or right behaviour based on moral judgements".

\section{Action}

To prevent unethical behaviour in homes for older persons, orientation programmes and in-service education programmes for auxiliary nurses and care workers are essential with regard to the factors as outlined in Tables 2 and 3. Orientation programmes should include the philosophy of the older persons' home and procedure manuals must be used to orientate the auxiliary nurses and care workers to their scope of practice and to guide them in the work situation. Inservice education programmes could take the form of practical demonstrations, videos and lectures (either formal or informal), visiting lecturers, the observation of practical procedures and the on-going supervision of the auxiliary nurse and care worker (Mellish, 1990:13).

\section{Guideline 4}

The legal-ethical framework should be used as a guideline for the behaviour of personnel in homes for older persons.

\section{Rationale}

From the factors identified in the findings, it was evident that the auxiliary nurse and care worker are not aware of the legal and ethical framework in respect of caring for older persons. This was evidenced by a general unethical and uncaring attitude towards the residents. The following quotes support the rationale: "She does not know about illegal hazard implications" and "The care worker does not know the legal implication".

\section{Action}

The following legislation should be evident in a home for the older persons:

- Aged Persons' Amendment Act, No 100 of 1998 (South Africa, 1998)

- Labour Relations Act, No 66 of 1995 (South Africa, 1995)

- Codes and Conduct (SANC, 1978)

- Human Rights Charter (South African Constitution, 2000)

- Guidelines for Management of Old Age Homes

- Disciplinary Procedures/Grievance Procedures.

\section{RECOMMENDATIONS}

The recommendations made are based on the research findings and the applicability thereof to homes for older persons.

- Adequate orientation and education programmes of professional values and practice for auxiliary nurses and care workers should be developed and implemented.

- A system of quality assurance/structure, process and outcome standards should be developed and implemented in homes for older persons.

- Moral sensitivity programmes should be developed to prepare the auxiliary nurse and care worker to understand the residents of the old age home in terms of their physical, spiritual and emotional needs.

- A formal recruitment and selection system/process for the recruitment of auxiliary nurses and care workers in homes for older persons should be initiated.

\section{LIMITATIONS OF THE STUDY}

The main limitation in the research method and sampling techniques was that the population and sample of nurses could have been larger. However, in the practice situation, auxiliary nurses are in the minority and care workers are in the majority. This situation is thus a factor when sampling techniques are applied.

\section{CONCLUSION}

This study highlighted the need for action to prevent unethical behaviour of auxiliary nurses and care workers in homes for older persons and the factors that contribute towards this situation. The problem of unethical behaviour in homes for older persons has existed for a number of years and the vulnerability of older persons at the hands of unethical behaviour is a distressing situation in health care institutions.

\section{LIST OF REFERENCES}

AFRICAN NATIONAL CONGRESS 1994: Reconstruction and Development Programme. Pretoria: Government Printer. AROSKAR, MA 1983: Ethical dilemmas and nursing practice; $2^{\text {nd }}$ edition. Connecticut: Appleton Century Crofts. 
BANDMAN, EL \& BANDMAN, B 1990: Nursing ethics through the lifespan. Cape Town: Appleton Century Crofts.

BREITUNG, JC 1987: Caring for the elder adults. Philadelphia: Saunders.

BRINK, HL 1996: Fundamentals of research methodology for health care professionals. Pretoria: University of South Africa.

BURNS, N \& GROVE, SK 1993: The practice of nursing research. Conduct, critique and utilisation; $2^{\text {nd }}$ edition. Philadelphia: Saunders. CARTE BLANCHE, 2000: Elder abuse. 23 January 2000 \& 13 February 2000. www.mnet.co.za/carteblanche/display/ display.asp? ld $=1593$.

CONCISE OXFORD DICTIONARY 1951: $4^{\text {th }}$ edition. Oxford: Oxford University Press.

CONRADIE, G \& CHARLTON, K 1992: Malpractices and mistreatment of residents in homes for the older persons. Report on a think-tank. HSRC/UCT Centre for Gerontology: University of Cape Town.

GROGAR-MURRAY, ME \& DICROCE, HR 1997: Leadership and management in nursing; $2^{\text {nd }}$ edition. Stanford: Appleton \& Lange. HOLLOWAY, I \& WHEELER, S 1996: Qualitative research in nursing; $2^{\text {nd }}$ edition. London: Blackwell.

LINCOLN, YS \& GUBA, EG 1985: Naturalistic inquiry. London: Sage. MELLISH, JM 1990: Preparing the nursing assistant. A comprehensive text. Durban: Butterworth.

MOUTON, JC \& MARAIS, HC 1990: Basic concepts in the methodology of the social sciences. Pretoria: Human Sciences Research Council.

MULLER, M 1998: Nursing dynamics; $2^{\text {nd }}$ edition. Sandton: Heineman.

PEROLD, AM 2000: Koste-effektiewe benutting van verpleegpersoneel in ouetehuise. Nursing Update, September:6. Pretoria: DENOSA.

POLIT, DF \& HUNGLER, BP 1993: Essentials of nursing research methods, appraisal and utilization; $3^{\text {rd }}$ edition. Philadelphia: JB Lippincott.

REILLY, D \& OESNAN, MN 1985: The clinical field: It's uses in nursing education. Cape Town: Appleton-Century Croft. SOUTH AFRICAN NURSING COUNCIL, 1978: Codes of conduct. Government Notice No R1649 as amended by No R480, 14 September 1973, 10 March 1978. Pretoria: SANC.

SOUTH AFRICAN NURSING COUNCIL, 1985: Relation to the approval of and the minimum requirements for the education and training of a nurse (general, psychiatric and community) and midwife leading to registration. Regulation 425 (as amended), Nursing Act 1978. Pretoria: SANC.

SOUTH AFRICAN NURSING COUNCIL, 1989: Regulations relating to minimum requirements for a course for a certificate leading to enrolment as nursing assistant, No. R1571, July 1989. Regulations R425 of 22/2/1985 and R753 of 22/2/1985. Pretoria: SANC.
SOUTH AFRICA (REPUBLIC). Labour Act No. 66 of 1995. Pretoria: Government Printer.

SOUTH AFRICA, 1998: Aged Persons Amendment Act, No. 100 of 1998: Manual of care of the aged in homes. Pretoria: Government Printer.

SOUTH AFRICAN CONSTITUTION 2000: Charter of Human Rights. Pretoria: Government Printer.

STEPHENSON, JC 1988: The nursing assistant's guide. Kenwyn: Juta.

TELLIS-NAYAK, V \& TELLIS-NAYAK, R. 1989: Quality of care and the burden of two cultures. When the world of the nurse's aid enters the world of the nursing home. Gerontological Society of America, 29(3):309.

WRIGHT, LK 1998: A reconceptualisation of the negative staff attitudes and poor care in nursing homes' assumption. Gerontologist, December, 28(6):3-14. 